Open Access

\title{
Re-estimation and comparisons of alternative accounting based bankruptcy prediction models for Indian companies
}

Bhanu Pratap Singh ${ }^{*}$ and Alok Kumar Mishra*

\author{
* Correspondence: bhanuatindia@ \\ gmail.com; misalok@gmail.com \\ School of Economics, University of \\ Hyderabad, Prof. C.R. Rao Road, \\ Gachibowli, Hyderabad-500046 \\ Telangana, India
}

\begin{abstract}
Background: The suitability and performance of the bankruptcy prediction models is an empirical question. The aim of this paper is to develop a bankruptcy prediction model for Indian manufacturing companies on a sample of 208 companies consisting of an equal number of defaulted and non-defaulted firms. Out of 208 companies, 130 are used for estimation sample, and 78 are holdout for model validation. The study reestimates the accounting based models such as Altman EI (Journal of Finance 23: 19189-209, 1968) Z-Score, Ohlson JA (Journal of Accounting Research 18:109-131, 1980) Y-Score and Zmijewski ME (Journal of Accounting Research 22:59-82, 1984) X-Score model. The paper compares original and re-estimated models to explore the sensitivity of these models towards the change in time periods and financial conditions.
\end{abstract}

Methods: Multiple Discriminant Analysis (MDA) and Probit techniques are employed in the estimation of Z-Score and X-Score models, whereas Logit technique is employed in the estimation of Y-Score and the newly proposed models. The performance of all the original, re-estimated and new proposed models are assessed by predictive accuracy, significance of parameters, long-range accuracy, secondary sample and Receiver Operating Characteristic (ROC) tests.

Results: The major findings of the study reveal that the overall predictive accuracy of all the three models improves on estimation and holdout sample when the coefficients are re-estimated. Amongst the contesting models, the new bankruptcy prediction model outperforms other models.

Conclusions: The industry specific model should be developed with the new combinations of financial ratios to predict bankruptcy of the firms in a particular country. The study further suggests the coefficients of the models are sensitive to time periods and financial condition. Hence, researchers should be cautioned while choosing the models for bankruptcy prediction to recalculate the models by looking at the recent data in order to get higher predictive accuracy.

Keywords: Bankruptcy prediction, Indian manufacturing companies, MDA, Logit, Probit, Unstable coefficient, Predictive accuracy, Receiver operating characteristic, Long range accuracy

JEL Classification Codes: G 33 


\section{Background}

The World Economy at the start of $21^{\text {st }}$ century begin with the financial crisis, which led to shift emphasis on modeling and evaluation of credit risk. The factors behind the shift in the trend are the rapid growth of the credit derivative market, rise in the bankruptcy and developing credit risk literature. The failure of rating agencies (Moody's, Standard and Poor's) to predict the fall of giant manufacturing companies like Chrysler, GM, LyondellBasell Industries, Excide Technologies alarmed the need to revisit risk management framework worldwide.

The current study proposes a new bankruptcy prediction model for Indian manufacturing companies. Since Beaver (1966), a substantial literature on bankruptcy prediction is developed to assess the financial health of companies. These models were based upon different theoretical approaches and types of information to model bankruptcy. Three notable and most cited accounting based bankruptcy models in the literature of accounting research are Altman (1968), Ohlson (1980) and Zmijewski (1984) (Grice and Dugan, 2001). The suitability and performance of these models in the new era is an empirical question due to change in time periods and financial conditions in which it was originally developed. The study re-estimates and compares these models with the newly proposed model.

In the bankruptcy prediction literature academician and accounting, practitioners have differed in the opinion on the power of these models to address the sensitivity of time periods and financial condition (cross-country heterogeneity, market structure, business cycle, etc.).

Begley et al. (1996) re-estimates and compares performance of original Altman's and Ohlson's models using US 1980's data. The major finding of the study suggests Altman's and Ohlson's model outperforms re-estimated model. Both the re-estimated model have higher classification errors. Out of four contesting models, Ohlson's original model outperforms other three contesting models. In line with Begley, Boritz et al. (2007) studying bankruptcy in Canada founds predictive accuracy of Altman's and Ohlson's original models are higher than re-estimated model. They also compared the accuracy of models developed for Canadian firms, namely, Springate (1978), Altman and Levallee (1980), and Legault and Veronneau (1986). The study concludes the Canadian models are being simpler and requiring less data. All models have stronger performance with the original coefficients than the re-estimated coefficients.

On the contrary, there are ample of studies questioning construct validity of the models to original models towards the change in time periods and financial conditions. Grice and Ingram (2001) analysed the sensitivity of Altman's Z-score model for US companies. The study suggests the coefficients of the models are sensitive to the change in the financial environment and time period. The re-estimated model with the most recent information give better predictive accuracy. Grice and Dugan (2001) conducted study on US companies founds predictive accuracy of re-estimated Altman's and Ohlson's model is higher than the original models. Timmermans (2014) analysed the sensitivity of Altman's, Ohlson's and Zmijewski's models on US companies. The major finding of the study suggests the re-estimated model have a higher predictive accuracy than the original models. Avenhuis (2013) conducted study on Dutch companies. The study re-estimates and compares performance of Altman's, Ohlson's and Zmijewski's original models. The major finding of the study suggests re-estimation of model with specific and bigger sample give better predictive accuracy. 
According to Platt and Platt (1990) the economic environment of two periods may change because of three reasons: First, change in the relationship between bankruptcy (dependent variable) and financial ratios. Second, change in the range of financial ratios (independent variables). And third, change in the relationship among financial ratios. They also suggested these changes attribute to bring change in the corporate strategy, the competitive nature of market, business cycle and technology. In the Indian market Bandyopadhyay (2006), Bhumia and Sarkar, (2011) and Shetty et al. (2012) developed Industry specific models for Indian corporate bond, pharmaceutical, and Information Technology/Information Technology Enabled Services (IT/ITES) industry respectively. Chudson (1945) mentions industry specific models are more appropriate than general models. The similar evidence is also found in the study of Avenhuis (2013).

In the light of above discussion the major aim of the paper is threefold: First, to develop a new bankruptcy prediction model for Indian manufacturing companies on Indian sample. Second, to revisits and re-estimate Altman (1968), Ohlson (1980) and Zmijewski (1984) models to examine the sensitivity of these models towards change in financial conditions and time periods. Finally, to choose the best model for prediction of financial distress of Indian manufacturing companies. The current study differs from prior study in three perspectives: Firstly, the study uses larger data set sampled over a longer period (Sample size 208) than in previous studies on Indian market which increases statistical power of the model. Second, the new bankruptcy prediction model is proposed with a unique combination of financial ratios measuring leverage, profitability and turnover of Indian manufacturing companies. Third, in the Indian market, there is no attempt is made to compare the sensitivity of Altman's, Ohlson's and Zmijewski's models together towards change in time period and financial conditions.

The major findings of the study reveal that the overall predictive accuracy of all the three models improves on estimation and holdout sample when the coefficients are reestimated. Amongst the contesting models, the new proposed model outperforms while predicting bankruptcy for Indian manufacturing companies. The study further suggests the coefficients of the models are sensitive to time periods and financial conditions. The relation between financial ratios and bankruptcy and the comparative importance of the financial ratios are also not constant over the time periods. The findings are in line with past studies of Grice and Ingram (2001), Grice and Dugan (2001), Timmermans (2014) and Avenhuis (2013). Hence, researchers should be cautioned while choosing the models for bankruptcy prediction to recalculate the models by looking at the recent data in order to get higher predictive accuracy. The remainder of this paper is organized as follows. Survey of literature is covered in section 2. Section 3 discusses considered models for the study. Section 4 deals with sample and development of new bankruptcy prediction models for Indian manufacturing companies. Re-estimations of models, results and discussion and evaluation of the model is done in section 5. The study concludes with section 6 which discusses the implications of those findings for users of the models.

\section{Survey of literature}

The formal studies on credit risk started in the 1930's (Altman, 1968). The early studies were univariate in nature, and single financial ratios were used to assess the financial position of the borrower. These studies set the platform for the further development of 
credit risk models. Some of the important univariate studies are Fitzpatrick (1932), Smith and Winaker (1935), Merwin (1942), Chudson (1945), Jackendoff (1962) and Beaver (1966). After seven decades of credit risk measurement, there is extensive development in the credit risk literature. The credit risk models can be classified into the following categories (Fejer-Kiraly, 2015):

1. Parametric Models (Accounting and market-based models) and

2. Non-parametric Models (Artificial Neural Networks (ANN), Hazard models, Fuzzy Models, Genetic Algorithms (GA) and Hybrid models, or models in which several of the former models are combined)

\section{Parametric models}

The parametric models could be univariate and multivariate in nature which uses mainly financial ratios and focuses on the symptoms of bankruptcy (Andan \& Dar, 2006). Sometimes these models uses non-financial information (Ohlson, 1980; Bandyopadhyay, 2006). Balcaen and Ooghe (2004) and Bellovary et al. (2007) are the most cited paper in literature of bankruptcy prediction. Both the papers focused on the problems of parametric models. These problems are related to assumptions on the dichotomous variable, the sampling method, stationarity assumptions, data instability, selection of independent variables, use of accounting information and the time dimension (Balcaen \& Ooghe, 2004). Further, parametric models can be classified into two categories: accounting based and market-based models. Market-based models are again divided into two parts structural and reduced form models.

\section{Accounting based models}

Beaver (1966) with his univariate default prediction study on US firms revolutionize the practice of credit risk assessment. The study compares the mean values of 30 financial ratios of 79 failed and 79 non-failed firms in 38 industries. Further, the study tests the ability of individual financial ratios to classify between bankrupt and non-bankrupt firms. Four financial ratios were found to have highest classification power, namely, net income to total debt (92\%), net income to net worth (91\%), cash flow to total debt (90\%), and cash flow to total assets (90\%). For future research, the study suggested multiple ratios considered simultaneously may have higher predictive ability than single ratios which created a platform for multiple ratio models.

Altman (1968) developed a first multivariate discriminant model for default prediction for US companies. The model uses five financial ratios to predict bankruptcy of the firms. The model can predict bankruptcy with $95 \%$ of accuracy for the initial sample one year prior to bankruptcy. Altman et al. (1977) developed a model for US manufacturing and retailers, which had the effective classifying ability from 5 years prior to default. Since Altman (1968), discriminant analysis is used by many researchers by making changes in financial ratios, study sample, and change in business culture. Some of the notable studies are Deakin (1972), Blum (1974), Springate (1978) and Fulmer (1984).

The limitations of discriminant analysis created space for the development of logit model. Ohlson (1980) introduced a logit model in the literature of bankruptcy prediction. The assumptions of logit model were different from Z-score models. Ohlson 
identified nine independent variables (financial and non-financial) based upon their frequent use in the bankruptcy prediction literature. The model was developed with the sample of 2163 companies (105 defaulted and 2058 non-defaulted) for the period 1970-1976. In line with Ohlson, Abdullah et al. (2008), applied the logistic model to foretell corporate failure of Malaysian firms. Further, Zmijewski (1984) applied probit technique using data of 40 bankrupt and 8000 non-bankrupt US firms for the period 1970-1978.

After logit and probit models, the number of studies attempted making comparison between logit, probit, and MDA analysis. In case of Thailand, Pongsatat et al. (2004) examines predictive capabilities of Ohlson's and Altman's models. The study concludes Altman model outperforms Ohlson model on the basis of predictive accuracy. Likewise, Ugurlu and Aksoy (2006) developed bankruptcy prediction model for Turkish firms using Altman's (1968) and Ohlson's (1980) statistical techniques. Further, Gu (2002) develops MDA model for estimating the failure of USA restaurant firms. In the Indian market, Bandyopadhyay (2006) develops a bankruptcy prediction model for the Indian corporate bond sector using MDA and logistic technique. Bhumia and Sarkar, (2011) developed a corporate failure model for the Indian pharmaceutical company based upon MDA technique. Ramkrishnan (2005) used discriminant and logistic model to foretell bankruptcy for Indian companies.

\section{Market-based models}

The market-based models are classified into structural (Merton 1974; Agarwal and Taffler 2008; Wu, Gaunt and Gray 2010; Hillegeist et al. (2004) and Bharath and Shumway 2008) and reduced (Jarrow and Turnbull 1995; Duffie and Singleton 1999 and Lando 1994) form models.

Black and Scholes (1973) option pricing theory which was extended by Metron (1974) is applied to model default in structural based models. In these models firms can default on its debt obligation only at the time of maturity. Later, some models were developed by extension to allow a default to occur before the date of maturity. These models were familiarized by Black and Cox (1976), Lonfstaff and Schwartz (1995), Leland and Toft (1996). On the other hand, reduced form models focus over modeling default explicitly as an intensity or compensator process. Some of the notable market-based studies in the Indian market based upon Board of Industrial and Financial Reconstruction (BIFR) reference are Varma and Raghunathan (2000), Kulkarni et al. (2005).

\section{Non-parametric models}

The non-parametric models are heavily dependent on computer technology and mainly multivariate in nature (Andan \& Dar, 2006). Some of the well-known non-parametric models are artificial neural networks (ANN), hazard models, fuzzy models, genetic algorithms (GA) and hybrid models, or models in which several of the former models are combined.

The ANN models can learn and adapt, from a data set, and they have the ability to capture non-linear relationships between variables which are also advantages of these models. The main shortcomings of the model are that they fail to explain causal relationships among their variables which restricts their application to practical management problems 
(Lee \& Choi, 2013). Kirkos (2015) in a survey paper on credit risk, which focuses mainly on artificial intelligence models published between 2009 and 2011. The information technology revolution in the 1990's helped artificial intelligence and managerial systems to grow and develop. This led to the development of a new set of bankruptcy prediction models known as neural networks. The study of Messier and Hansen (1988) is linked to the use of neural networks in bankruptcy prediction. This is followed by number of studies (Bellovary et al. 2007) such as Raghupathi et al. (1991), Coats and Fant (1993), Guan (1993), Tsukuda and Baba (1994), and Altman, Marco, and Varetto (1994).

Apart from neural network, there are other non-parametric models, namely, hybrid model. The hybrid models are use of two models either parametric or non-parametric (Lee et al. 1996). Genetic algorithm is also one of the prominent other non-parametric models which work as a stochastic search technique to find out a company goes bankrupt or not (Varetto, 1998). Other widely used non-parametric models are: genetic programming (Etemadi et al., 2009), models based on "rough test" theory (Dimitrias et al. 1999), Bayesian, Fuzzy, Hazard and Data Envelopment Analysis (DEA).

After 2005, the artificial intelligence-based models became more famous and widely used. Premachandra et al. (2009) compares LR and DEA models and concluded DEA models have a better predictive accuracy to predict bankrupt firms (between $84 \%$ and $89 \%$ ), but the LR is more accurate in predicting healthy firms (between $69.3 \%$ and $99.47 \%)$. Verikas et al. (2010) conducted a study which reviews hybrid models and ensemble-based soft computing techniques applied in default prediction. Fuzzy logic approach is used by Korol and Korodi (2011). The model is based upon the financial data of 132 companies (107 non-bankrupt and 25 bankrupt). Gupta et al. (2014) conducted study which uses discrete-time hazard model on the data base of 385,733 nonbankrupt and 8,162 bankrupt SMEs. The study develops three hazard models for micro-, small-, and medium-sized firms. The study further suggests the financial reports do not provide sufficient information about the default of the micro-firms.

Shetty et al. (2012) develops early warning system for Indian IT/ITES using Data Envelopment Analysis (DEA). Kumar and Rao (2015) develops non-linear new Z-score model based upon Person Type-3 distribution for Indian companies.

\section{Methods}

\section{Considered models}

Over the past four decades, various credit risk models were developed based upon alternative approaches to model bankruptcy. Use of accounting ratios is always dominated the literature of bankruptcy prediction because of its simplicity and larger applicability to the firms. The current study examines three well-known accounting based bankruptcy prediction models. They are:

(i) Altman (1968) Z-score model based upon Multiple Discriminant Analysis (MDA)

(ii) Ohlson (1980) Y-score model based upon Logit Analysis

(iii) Zmijewski (1984) X-score model based upon Probit Analysis

Altman (1968) developed a bankruptcy prediction model which uses financial ratios that measures liquidity, profitability, leverage and solvency of the firm. The model uses 
MDA framework to model bankruptcy on 33 defaulted and 33 non-defaulted US manufacturing firms for the period 1946-1965. Equation (1) represents the original model estimated by Altman (1968):

$$
Z=1.2 W C T A+1.4 R E T A+3.3 E B I T A+0.6 M V E B V D+.99 S L T A
$$

Where $\mathrm{Z}$ is the overall index used to determine the membership of firms in defaulted or non-defaulted groups. The firm with $Z \geq 2.675$ is classified as non-bankrupt, whereas firm with $\mathrm{Z}<2.675$ is classified as bankrupt firms. WCTA to SLTA are accounting variables used in the model whose description is given in Table 1 .

Ohlson (1980) employed a logit technique with less restrictive assumptions than those taken in the MDA approach to model bankruptcy. The model uses nine predictive variables which measures firms' size, leverage, liquidity, and performance. The estimated model consist 105 bankrupt and 2,058 non-bankrupt industrial firms for the period 1970-1976. The original model is shown in equation (2):

$$
\begin{aligned}
Y= & -1.3-0.4 \text { SIZE }+ \text { 6.0TLTA-1.4WCTA }+0.1 \text { CLCA-2.4OENEG-1.8NITA } \\
& +\quad 0.3 F U T L-1.7 \text { INTWO-0.5CHIN }
\end{aligned}
$$

Where, $\mathrm{Y}$ is the overall index based upon logistic function which determine the probability of firms' membership in default or non-default group. Based upon total error minimization ${ }^{1}$ criterion for the given data firm with $\mathrm{Y}>0.5$ is classified defaulted firm otherwise non-defaulted (Ohlson 1980, page 120). The description of variables is provided in Table 1.

Zmijewski (1984) adopts a probit method to model bankruptcy which uses financial ratios measuring firm's performance, leverage, and liquidity. The ratios were selected on the basis of their performance in the previous studies. The model uses 40 bankrupt and 800 non-bankrupt industrial firms' data for the period 1972-1978. Equation (3) represents the original model estimated by Zmijewski (1984):

$$
\mathrm{X}=-4.3-4.5 \mathrm{NITL}+5.7 \mathrm{TLTA}-.004 \mathrm{CACL}
$$

Where, $\mathrm{X}$ is the overall index based upon probit function which determines the probability of firms' membership in bankrupt and non-bankrupt group. Again based upon total error minimization criterion firm with $\mathrm{X}>0.5$ is classified bankrupt firm otherwise non-defaulted (Zmijewski 1984, page 72). NITL, TLTA, and CACL are the variables used in the model which details are provided in Table 1.

\section{The new bankruptcy prediction model for indian manufacturing companies}

This section covers the development of new bankruptcy prediction model for Indian manufacturing companies. The new bankruptcy prediction model is developed on sample of 208 equal numbers of defaulted and non-defaulted Indian manufacturing firms for the period 2006-2014. Out of 208 companies 130 used for estimation sample and 78 holdout for model validation.

\section{Sample}

The analysis reported here used estimation and a hold-out sample, with each sample including distressed and non-distressed firms. The Board of Industrial and Financial Reconstruction (BIFR) reference is used to identify distressed firms from the list of 
Table 1 Summary of Empirical Models Employed and Variables Employed

\begin{tabular}{|c|c|c|c|}
\hline Models & Formula & Variables & Descriptions \\
\hline Altman (1968) Multiple Discriminant Analysis & $\begin{array}{l}Z=\beta^{\prime} X \\
\text { Where } Z \text { is the MDA score and } X \text { represent the variables listed. } \\
\text { Cutoff value: } Z \geq 2.675 \text {, classified as non-bankrupt } \\
Z<2.675 \text {, classified as bankrupt }\end{array}$ & $\begin{array}{l}\text { WCTA } \\
\text { RETA } \\
\text { EBITA } \\
\text { MVEBVD } \\
\text { SLTA }\end{array}$ & $\begin{array}{l}=\text { Net Working Capital/Total Assets } \\
=\text { Retained earnings/Total Assets } \\
=\text { Earnings before interest and taxes/Total assets } \\
=\text { Market value of equity/Book value of total liabilities } \\
=\text { Sales/Total Assets }\end{array}$ \\
\hline Ohlson (1980) Logit Model & $\begin{array}{l}P=\left(1+\exp \left\{-\beta^{\prime} X\right\}\right)^{-1} \\
\text { Where } P \text { is the probability of bankruptcy and } X \text { represents the } \\
\text { variables listed. The logit function maps the value of } \beta^{\prime} X \text { to a } \\
\text { probability bounded between } 0 \text { and } 1 . \\
\text { Cutoff value: } \\
Y>0.5 \text {, classified as defaulted otherwise non-defaulted. }\end{array}$ & $\begin{array}{l}\text { SIZE } \\
\text { TLTA } \\
\text { WCTA } \\
\text { CLCA } \\
\text { OENEG } \\
\text { NITA } \\
\text { FUTL } \\
\text { INTWO } \\
\text { CHIN }\end{array}$ & $\begin{aligned}= & \text { Log }(\text { Total assets/GNP price-level index). Index with a base } 100 \text { for } 1968 . \\
= & \text { Total liabilities/Total Assets } \\
= & \text { Working capital/Total Assets } \\
= & \text { Current Liabilities/Current Assets } \\
= & 1 \text { If total liabilities exceed total assets, } 0 \text { otherwise. } \\
= & \text { Net income/Total assets } \\
= & \text { Funds provided by operations (income from operation after } \\
& \text { depreciation) divided by total liabilities. } \\
= & 1 \text { If net income was negative for the last } 2 \text { years, } 0 \text { otherwise. } \\
= & \left(N I_{t}-N I_{t-1}\right) /\left(\left|N I_{t}\right|+\left|N I_{t-1}\right|\right) \text { where, } N t_{t} \text { is net income for the most } \\
& \text { recent period. The denominator acts as a level indicator. } \\
& \text { The variable is thus intended to measure the relative change } \\
& \text { in net income. }\end{aligned}$ \\
\hline $\begin{array}{l}\text { Zmijewski (1984) } \\
\text { Probit model }\end{array}$ & $\begin{array}{l}P=\phi\left(\beta^{\prime} X\right) \\
\text { Where, } P \text { is the probability of bankruptcy and } X \text { represents } \\
\text { the variables listed, and } \phi(.) \text { represents the cumulative normal } \\
\text { distribution function. The probit function maps the value } \beta^{\prime} X \text { to } \\
\text { a probability bounded between } 0 \text { and } 1 . \\
\text { Cutoff value: } \\
X>0.5 \text {, classified as bankrupt, otherwise non-bankrupt. }\end{array}$ & $\begin{array}{l}\text { NITL } \\
\text { TLTA } \\
\text { CACL }\end{array}$ & $\begin{array}{l}=\text { Net income divided by total liabilities. } \\
=\text { Total liabilities divided by total assets. } \\
=\text { Current assets divided by current liabilities. }\end{array}$ \\
\hline
\end{tabular}

Note: The cutoff value of Ohlson (1980) and Zmijewski (1984) models are decided using total error minimisation criterion (Ohlson 1980 page 120; Zmijewski 1984 page 72)

Source: Author's compilation 
firm's registered sick during 2006 to 2014. A set of matched non-distressed companies are identified randomly on the basis of asset size and industry type. A total of $130 \mathrm{com}$ panies comprising distressed and non-distressed companies are used for estimation sample. A sample of 78 companies' holdout for model validation. Financial information of the companies is collected from their balance sheet and income statements. The Balance sheet and income statements of the companies at the end of each year are collected from their respective websites. The estimated and holdout sample have been classified into 14 industry category matching with their economic activity with the National Industrial Classification Code (NIC) 3 digit classification of 2008 (See Table 2).

\section{Selection of financial ratios}

There is extensive literature on the use of financial ratios to predict bankruptcy of the firms. Since Beaver (1966), various financial ratios were tried to foretell bankruptcy, and they can be broadly classified into four categories, which measures firm's leverage, liquidity, profitability and turnover. Bellovary et al. (2007), in a survey paper on bankruptcy prediction list 42 financial ratios which is used in more than five financial studies on bankruptcy prediction.

In the Indian market, Bandyopadhyay (2006) develops bankruptcy prediction model based upon MDA and logistic technique for Indian corporate bond sector. The ratios used in his study measures liquidity, leverage, productivity, turnover and other financial variables which measures age, group ownership, ISO Quality Certification and interindustry effects of the firms. Bhumia and Sarkar (2011) in other study on Indian pharmaceutical industry developed model for corporate failure using MDA technique. The study chooses 16 financial ratios based upon past empirical literature measuring

Table 2 Distribution of Firms as per NIC Classification 2008

\begin{tabular}{|c|c|c|c|c|}
\hline $\begin{array}{l}\mathrm{NIC} \\
\text { Code }\end{array}$ & Sector & $\begin{array}{l}\text { Estimation } \\
\text { Sample }\end{array}$ & $\begin{array}{l}\text { Holdout } \\
\text { Sample }\end{array}$ & Total \\
\hline 107 & Manufacturer of other food products & 14 & 6 & 20 \\
\hline 131 & Spinning, weaving and finishing of textiles & 34 & 16 & 50 \\
\hline 170 & Manufacturer of paper and paper products & 4 & 10 & 14 \\
\hline 201 & $\begin{array}{l}\text { Manufacturer of basic chemicals, fertilizer and nitrogen } \\
\text { compounds, plastics, synthetic rubber in primary form }\end{array}$ & 18 & 6 & 24 \\
\hline 210 & $\begin{array}{l}\text { Manufacturer of pharmaceuticals, medicinal chemical } \\
\text { and botanical products }\end{array}$ & 6 & 2 & 8 \\
\hline 221 & Manufacturer of rubber products & 4 & 4 & 8 \\
\hline 231 & Manufacturer of glass and glass products & 4 & 2 & 6 \\
\hline 239 & Manufacturer of non-metallic mineral products n.e.c. & 2 & & 2 \\
\hline 243 & Casting of metals & 16 & 6 & 22 \\
\hline 261 & Manufacturer of electronic components & 6 & 16 & 22 \\
\hline 271 & $\begin{array}{l}\text { Manufacturer of electric motors, generators, transformers } \\
\text { and electricity distribution and control apparatus }\end{array}$ & 4 & & 4 \\
\hline 291 & Manufacturer of motor vehicles & 8 & 6 & 14 \\
\hline 310 & Manufacturer of furniture & 4 & & 4 \\
\hline \multirow[t]{2}{*}{492} & Other land transport & 6 & 4 & 10 \\
\hline & Total & 130 & 78 & 208 \\
\hline
\end{tabular}

Source: Author's compilation 
profitability, solvency, liquidity and efficiency of the firms. Shetty et al. (2012) develops early warning system for Indian IT/ITES using Data Envelopment Analysis (DEA). Based upon the past empirical studies ten financial ratios measuring firm's liquidity, leverage, productivity, and turnover. Kumar and Rao (2015) develops non-linear new Zscore model based upon Person Type-3 distribution for Indian companies. In addition to Altman (1968) variables, the study uses two other non-financial variables measuring industry effects and rating of the companies. Based upon the past empirical literature and our own analytical judgment, we have chosen 25 financial ratios measuring firm's leverage, liquidity, profitability, and turnover. In most of studies on global or Indian market, they found leverage, liquidity, profitability and turnover are the major financial ratio which predicts corporate failure.

Out of four major financial ratio leverage is considered to be one of the important ratios to assess financial position of the firms. According to Argenti (1976) in his study, he founds high indebtedness of the firms is one of the major reason leading a firm to bankruptcy. Similarly, Jensen (1989) argues leverage is an invitation to bankruptcy, and high debt ratios are not good for firms. In the Indian market Bandyopadhyay (2006), Bhumia and Sarkar (2011), Shetty et al. (2012) and Kumar and Rao (2015) acknowledges the importance of leverage ratio and uses different leverage indicators to assess bankruptcy. Except Bhumia and Sarkar (2011) all other studies (Bandyopadhyay (2006), Shetty et al. (2012) and Kumar and Rao (2015)) on Indian market have taken market value of equity to book value of total debt as ratio measuring leverage of the firms. In lieu of past empirical literature and importance of the indicators including market value of equity to book value of total debt, 11 leverage ratios are chosen out of 25 financial ratios.

Liquidity is also considered to be one of the important ratio to assess credit worthiness of firms. Beaver (1966) in his study found the firms with lower liquid assets are more prone to bankruptcy. In line with Beaver (1966), Altman, Haldeman and Narayana (1977), Charalambrus, Charitiu and Kaourou (2000) and Platt and Platt (2002) also gets the similar findings. In the Indian market Bandyopadhyay (2006), Bhumia and Sarkar (2011), Shetty et al. (2012) and Kumar and Rao (2015) all have used liquidity indicator including working capital to total assets as a common liquidity indicator used in all the four empirical studies. In the current study including working capital to total assets, four liquidity indicators are used out of 25 financial ratios.

Profitability ratios measures the performance of the firms. The ratio explains how efficient and effective utilization of its assets and management of its expenditure to produce adequate earnings for its shareholders. According to $\mathrm{Gu}$ (2002), unprofitable firms are more likely to default. Izan (1984), Maricca and Georgeta (2012) also got similar findings in their respective studies. In the Indian context Bandyopadhyay (2006) uses operating profits to total assets as the proxy for profitability indicator. Kumar and Rao (2015) and Bhumia and Sarkar (2011) uses retained earnings to total assets as a proxy for profitability indicator. In the current study out of 25 financial ratio, 7 profitability ratios are chosen.

Turnover ratio measures efficiency of firms in utilizing their assets. Eljilly (2001) argues high efficiency leads to company profitable and less chance of bankruptcy and vice-versa. It measures the ability of companies to generate sales by the capital invested. Molinero and Ezzamel (1991) and Laitnen (1992) also founds the similar results. In the 
Indian market, Bandyopadhyay (2006) and Kumar and Rao (2015) have chosen Sales to Total Assets as proxy for turnover ratio. In the present study including Sales to Total Assets, 2 other turnover ratios are taken out of 25 ratios. The profile of variables used in the study is reported in Table 3. To check industry specific effects, the sample firms have been divided into 14 industry dummies based upon major economic activity as per NIC classification (Table 5).

Following steps are followed to select final profile of the ratios:

Step-I: Analysis of Variables: We have chosen 25 financial ratios on the basis of past empirical literatures on Indian market. Analyses on these ratios are carried out in two broad steps. First, mean and standard deviation of bankrupt and non-bankrupt firms are analysed. Second, $T$-test for equality in means of bankrupt and non-bankrupt groups are analysed.

Table 3 Profile of Financial Ratios

\begin{tabular}{|c|c|c|}
\hline SI No. & Financial Ratio & Calculations \\
\hline & Leverage Ratios & \\
\hline 1 & TDTA & Total Debt/Total Assets \\
\hline 2 & BVEBVD & Book Value of Equity/Book Value of Total Debt \\
\hline 3 & CFOTA & Cash Flow from Operations/Total Assets \\
\hline 4 & CLTA & Current Liabilities/Total Assets \\
\hline 5 & CFTD & Cash Flow from Operations/Total Debt \\
\hline 6 & LTDTA & Long-term Debt/Total Assets \\
\hline 7 & NWTA & Net Worth/Total Assets \\
\hline 8 & TDNW & Total Debt/Net Worth \\
\hline 9 & TLNW & Total Liabilities/Net Worth \\
\hline 10 & TLTA & Total Liabilities/Total Assets \\
\hline \multirow[t]{2}{*}{11} & FUTL & Fund Provided by Operations to Total Liabilities \\
\hline & Liquidity & \\
\hline 12 & CACL & Current Assets/Current Liabilities \\
\hline 13 & WCTA & Working Capital/Total Assets \\
\hline 14 & CATA & Current Assets/Total Assets \\
\hline \multirow[t]{2}{*}{15} & CLCA & Current Liabilities/Current Assets \\
\hline & Profitability & \\
\hline 16 & NITA & Net Income/Total Assets \\
\hline 17 & RETA & Retained Earnings/Total Assets \\
\hline 18 & EBITA & Earnings Before Interest and Taxes/Total Assets \\
\hline 19 & NINW & Net Income/Net Worth \\
\hline 20 & CASL & Current Assets/Sales \\
\hline 12 & NISL & Net Income/Sales \\
\hline \multirow[t]{2}{*}{22} & NITL & Net Income/Total Liabilities \\
\hline & Turnover & \\
\hline 23 & SLTA & Sales/Total Assets \\
\hline 24 & WCSL & Working Capital/Sales \\
\hline 25 & WCNW & Working Capital/Net Worth \\
\hline
\end{tabular}


Step-II: Step-wise regression: Forward logistic selection and backward elimination methods are applied and different combinations of the ratios which are significantly different in mean by $T$-test are tested and the final set of ratio are selected on the basis of the statistical significance of the estimated parameters, the sign of each variable's coefficient and the model's classification results.

Step-III: Inclusion of industry dummy: In the next step along with four financial ratios 14 industrial dummies were included in the model but none of them are found to be significant. This is also tested trough through stepwise regression model. However, the results are unchanged.

Step-IV: Final profile of the ratios: Finally, all the financial ratios which are found to be statistically significant chosen for the model.

\section{Analysis of variables}

This sections covers analysis of mean and standard deviation of defaulted and nondefaulted firms. T-test for equality in mean is employed to check weather defaulted, and non-defaulted groups have significantly different in their respective means. It is well-known from past empirical studies that the bankrupt companies have higher indebtedness, lower liquidity, poor profitability and turnover ratios. Also from Table 4, out of three turnover ratios, WCSL mean is not found to be statistically different. For defaulted groups it is found to be negative (WCSL and WCNW) and lower (SLTA) than the defaulted groups. In case of profitability indicators, out of 7 financial ratios all means are found to be significant expect CASL and NISL. For most of the profitability indicators, the ratio is found to be negative (NITA, RETA, EBITA, and NITL) for defaulted groups except NINW. For liquidity indicators out of 4, 2 turned to be statistically different means (WCTA, CLCA) and others are insignificant (CACL, CATA). In case of leverage indicators, all indicators are statistically different in mean except CLTA. For defaulted groups the ratios are found to be negative for all indicators except TDTA and TLTA. From the analysis on variables, in general, most of ratios are grouped under liquidity, profitability and turnover ratios have shown negative signs and declining for bankrupt companies.

$T$-test for equality in means for defaulted and non-defaulted groups shows out of 25 financial ratios chosen for the model, 19 ratios have statistically different in mean between defaulted and non-defaulted groups.

\section{Step-wise regression}

In a step-wise regression, logistic forward selection and backward elimination methods were applied and different combinations of the ratios (19 ratios) which had significantly different in their respective means are tested. The selections of the final set of the variables are based upon statistical significance and sign of the each of the variable coefficients. The model classification power also took into consideration. The similar method is also used by Neophytou et al. (2001) conducting study for Netherland firms. The final set of ratios and their statistical significance is reported in third column (Model 2) of Table 7. From Table 7 all the set of financial ratios are significant at $1 \%$ to $10 \%$ level of significance, and LR ratio shows the overall significance of the model. 
Table 4 Descriptive Statistics of the Financial Ratios

\begin{tabular}{|c|c|c|c|c|c|c|c|c|c|c|}
\hline Sample & Statistic & NITA & $\mathrm{CACL}$ & WCTA & RETA & EBITA & SLTA & TDTA & CATA & NINW \\
\hline \multirow[t]{2}{*}{ Distressed } & Mean & -0.290 & 2.519 & 0.215 & -0.295 & -0.100 & 0.984 & 1.151 & 0.714 & 2.257 \\
\hline & SD & 0.321 & 3.951 & 0.538 & 0.322 & 0.26 & 1.041 & 0.651 & 0.833 & 3.946 \\
\hline \multirow[t]{3}{*}{ Non-Distressed } & Mean & 0.044 & 3.496 & 0.553 & 0.034 & 0.152 & 2.013 & 0.723 & 0.961 & 0.054 \\
\hline & SD & 0.094 & 6.428 & 0.788 & 0.08 & 0.14 & 2.966 & 0.627 & 1.058 & 0.185 \\
\hline & $P$-Value & 0.000 & 0.299 & 0.005 & 0.000 & 0.000 & 0.009 & 0.000 & 0.142 & 0.000 \\
\hline Sample & Statistic & MVEBVD & CFOTA & CLTA & CFTD & CASL & NISL & LTDTA & NWTA & TDNW \\
\hline \multirow[t]{2}{*}{ Distressed } & Mean & -0.157 & -0.159 & 0.499 & -0.205 & 39.016 & -23.170 & 1.151 & -0.287 & -14.589 \\
\hline & SD & 0.200 & 0.262 & 0.571 & 0.409 & 250.959 & 114.765 & 0.651 & 0.485 & 40.268 \\
\hline \multirow[t]{3}{*}{ Non-Distressed } & Mean & 0.481 & 0.104 & 0.407 & 0.132 & 0.861 & 0.012 & 0.723 & 0.48 & 1.858 \\
\hline & SD & 0.300 & 0.128 & 0.436 & 0.999 & 1.830 & 0.447 & 0.627 & 0.420 & 1.835 \\
\hline & $P$-Value & 0.000 & 0.000 & 0.307 & 0.013 & 0.223 & 0.106 & 0.000 & 0.000 & 0.001 \\
\hline Sample & Statistic & TLNW & WCSL & WCNW & TLTA & CLCA & FUTL & $\mathrm{NITL}$ & & \\
\hline \multirow[t]{2}{*}{ Distressed } & Mean & -23.578 & -41.127 & -5.685 & 1.681 & 0.821 & -0.091 & -0.191 & & \\
\hline & SD & 76.339 & 342.421 & 29.01 & 0.982 & 0.693 & 0.116 & 0.230 & & \\
\hline \multirow[t]{3}{*}{ Non-Distressed } & Mean & 2.859 & 0.305 & 1.094 & 1.150 & 0.560 & 0.129 & 0.360 & & \\
\hline & SD & 2.451 & 1.060 & 0.932 & 0.873 & 0.427 & 0.371 & 2.586 & & \\
\hline & $P$-Value & 0.006 & 0.331 & 0.062 & 0.001 & 0.011 & 0.000 & 0.089 & & \\
\hline
\end{tabular}


Table 5 Industry Dummies for Sample Companies

\begin{tabular}{lll}
\hline Industry Dummy & Industry Type & No of Firms \\
\hline D1 & Manufacturer of other food products & 14 \\
D2 & Spinning, weaving and finishing of textiles & 34 \\
D3 & Manufacturer of paper and paper products & 4 \\
D4 & Manufacturer of basic chemicals, fertilizer and nitrogen \\
& compounds, plastics, synthetic rubber in primary form & 18 \\
D5 & Manufacturer of pharmaceuticals, medicinal chemical, and & 6 \\
D6 & botanical products & 4 \\
D7 & Manufacturer of rubber products & 4 \\
D8 & Manufacturer of glass and glass products & 2 \\
D9 & Manufacturer of non-metallic mineral products n.e.c. \\
D10 & Casting of metals & 16 \\
D11 & Manufacturer of electronic components & 6 \\
& Manufacturer of electric motors, generators, transformers & 4 \\
D12 & and electricity distribution and control apparatus \\
D13 & Manufacturer of motor vehicles & 8 \\
D14 & Manufacturer of furniture & 4 \\
& Other land transport & 6 \\
\hline
\end{tabular}

Source: Author's compilation

\section{Inclusion of industry dummy}

To capture the industry specific effects, our sample is characterized into 14 major industries based upon NIC 3 digit industrial classification code (Table 5). In the Indian case, similar kind of approach was adopted by Bandyopadhyay (2006), and Kumar and Rao (2015). Again along with four financial ratios 14 industrial dummies are included in the model, but none of them are found to be significant. Even different combination of specific industry dummies is tried but none of the turned to be significant. Finally, we have decided to drop dummies and go with only financial ratios (Table 7, Model 2).

\section{Final profile of the ratios}

The final profile of the financial ratios used in the model are:

BVEBVD (Book Value of Equity/Book value of Total Liabilities): This indicator measures leverage of the firms. The similar ratio is also used in the study of Altman (1968) on US manufacturing companies. In the current study market value of equity is replaced by book value of equity. The current study uses data of both publicly and privately held firms. In order to calculate market value of equity, stock price data (Altman, 1993) is required. The same principle is employed while re-estimating Altman's model. The ratio is found to be most effective predictor of bankruptcy than a similar, more commonly used ratio: net worth/total book value of debt. The indicator explains how much the firm's asset can decline in value before the liabilities exceed the assets, and the firm becomes bankrupt. In the Indian case of India, Bandyopadhyay (2006), Shetty et al. (2012) and Kumar and Rao (2015) uses this indicator to predict bankruptcy. SLTA (Sales/Total Assets): It is one of the widely used turnover ratio of firms. It measures efficiency and effectiveness of the firm's assets to generate profit. This is a 
key variable for the measurement of the size of the firm. The capital-turnover ratio is a standard financial ratio illustrating the sales generating ability of the firm's assets. It is one measure of management's capability in dealing with competitive conditions. It is used in the study of Altman (1968) and Bandyopadhyay (2006) and Kumar and Rao (2015), used in the Indian market.

NITA (Net Income/Total Assets): It is the ratio of net income to total assets which is a measure of performance of the firms. It measures profitability and also used in the study of Ohlson (1980) on US manufacturing companies.

NITL (Net Income/Total Liabilities): It is the ratio of net income to total liabilities. The ratio measures return on asset which is the measure of firm's performance and profitability. The ratio is also used in the study of Zmijewski (1984).

Broadly all the ratios used in the current study are from the studies of Altman (1968), Ohlson (1980) and Zmijewski (1984). The first two ratio's BVEBVD and SLTA measuring leverage and turnover of the firms are also used in the Study of Altman (1968). Third ratio NITA measures profitability of the firms is used in the study of Ohlson (1980), and fourth NITL measures profitability of firm is also applied in the study of Zmijewski (1984). The new bankruptcy prediction model uses ratios measuring leverage, profitability, and turnover of the firms. The model is also considered to be comprehensive model because it uses variables from all three major accounting based bankruptcy prediction model mentioned above. By 'Common Sense' and past studies all the variables are expected to have negative sign (Ohlson 1980, page 119).

Table 6 reports descriptive statistics of the variable used in the new model. The mean BVEBVD for non-defaulted group for both estimation (0.481) and holdout (3.359) sample respectively are found to be positive for non-defaulted and negative for defaulted groups. SLTA measures the firms' market size. For non-defaulted groups, the size is larger on both estimation (2.013) and holdout (2.522) whereas for defaulted groups its value is smaller on both estimation (0.984) and (1.521) holdout samples respectively. NITA is a ratio which measures firms' performance. The ratio deteriorates and found to be negative for bankrupt companies on estimation $(-0.289)$ and holdout $(-0.843)$ sample, whereas it is positive for non-bankrupt firms. NITL measures return on asset which is a measure of firm performance. For defaulted groups it is negative on both

Table 6 Descriptive Statistics of the Final Profile of the Financial Ratios

\begin{tabular}{llllll}
\hline Sample & Statistic & BVEBVD & SLTA & NITA & NITL \\
\hline Estimation & & & & & \\
\multicolumn{1}{c}{ Distressed $(\mathrm{N}=65)$} & Mean & -0.157 & 0.984 & -0.289 & -0.191 \\
& SD & 0.200 & 1.040 & 0.321 & 0.230 \\
Non-Distressed $(\mathrm{N}=65)$ & Mean & 0.481 & 2.013 & 0.044 & 0.360 \\
& SD & 0.299 & 2.965 & 0.094 & 2.586 \\
Holdout & & & & & \\
Distressed $(\mathrm{N}=39)$ & Mean & -0.157 & 1.521 & -0.843 & -0.192 \\
& SD & 0.264 & 1.919 & 1.863 & 0.602 \\
Non-Distressed $(\mathrm{N}=39)$ & Mean & 3.359 & 2.522 & 0.110 & 0.094 \\
& SD & 7.173 & 3.111 & 0.169 & 0.160 \\
\hline
\end{tabular}


estimation (-0.191) and holdout (-0.192) sample, whereas the ratio is found to be positive for non-bankrupt firm on both estimation (0.360) and holdout (0.094) sample respectively.

\section{Logit model: estimation procedure}

The logistic regression method is used to investigate the relationship between binary response variable ( 1 for bankrupt and 0 for non-bankrupt groups) and financial ratios (explanatory variables). The Maximum Likelihood Estimation (MLE) procedure is applied to estimate parameters. The objective of the logit regression is to evaluate the role of accounting variables in predicting bankruptcy for Indian manufacturing firms and also to arrive at an estimate of probability of default for a firm using them.

\section{Logit model}

If a dependent variable is binary and is a function of set of independent variables, the Linear Probability Model (LPM) can be written as:

$$
P_{i}=E\left(Y=1 \mid X_{i}\right)=\beta_{1}+\beta_{2} X_{i}
$$

Where, Pi represents probability, $X_{i}$ represents various financial ratios of the firms and $\mathrm{Y}$ is the dependent variable. $\mathrm{Y}=1$ means the firm is failed. $\beta_{1}$ and $\beta_{2}$ are slope coefficients.

The intrinsic defects of LPM given birth to Logit and Probit models. In LPM (1) the probability of $Y$ can exceeds the limit of 0 and 1 . Hence, the useful way to solve the problem is to transform $X_{i}^{\prime}$ and $\beta^{\prime}$ s into a probability with function $\mathrm{F}$ that translates $\mathrm{X} \beta$ into number between 0 and 1 .

$$
\operatorname{prob}\left(y_{i}=1\right)=F\left(X_{i} \beta\right)
$$

Where $\mathrm{F}$ is cumulative density function.

Choosing $\mathrm{F}$ to be the logistic distribution yields one of the ways to limit prob $\left(\mathrm{y}_{i}=1\right)$ between 0 and 1 . This is called the logit model.

$$
\operatorname{prob}\left(y_{i}=1\right)=\Lambda\left(X_{i} \beta\right)=\frac{\exp X_{i} \beta}{1+\exp X_{i} \beta}
$$

In the context of default prediction study, the logit model is used to classify whether a company is defaulted or non-defaulted by using accounting-based financial ratios.

\section{Estimation results}

In the logit regression, dependent variables is defined as a binary variable taking value 1 for defaulted and 0 for non-defaulted groups. The balanced sample for 130 campiness consisting equal number of defaulted and non-defaulted groups for the period 2006 to 2014 has been used to run logit model. In a stepwise logistic regression applying forward and backward elimination method is used, and finally, we obtained two models (Table 7). In Model 1 along with significant financial ratios all the dummies are incorporated to check industry effects but all financial ratios and dummies turned to be insignificant. Model 2 is taken as final model which uses only financial variable. In case of model 2 all variables are significant and preserves expected sign. From Table 7, in case of Model 2 BVEBVD is negatively significant at $1 \%$ level on default probability. NITA and NITL are negatively significant (5\% level) with default probabilities. In case of SLTA, it is also negatively significant at $10 \%$ level of significance. 
Table 7 Results of Logit Model 1 and 2

\begin{tabular}{lll}
\hline & Model 1 & Model 2 \\
\hline Variables & Coefficients & $-13.8597^{\mathrm{a}}$ \\
MVEBVD & -39.907 & $-1.11303^{\mathrm{c}}$ \\
SLTA & -4.488 & $-18.760^{\mathrm{b}}$ \\
NITA & -72.776 & $-34.354^{\mathrm{b}}$ \\
NITL & -107.685 & -0.604 \\
C & -7.012 & \\
D1 & 13.256 & \\
D2 & 6.277 & \\
D3 & -14.496 & \\
D4 & Dropped & \\
D5 & -2.311 & \\
D6 & 8.592 & \\
D7 & 10.97 & \\
D8 & Dropped & \\
D9 & 3.865 & \\
D10 & 15.956 & \\
D11 & Dropped & \\
D12 & -1.563 & \\
D13 & Dropped & \\
D14 & 7.767 & \\
LR Ratio & 172.219 & \\
p-Value & 0.000 & \\
\hline Dote & 1960 & \\
\hline
\end{tabular}

Note: ${ }^{\mathrm{a}}{ }^{\mathrm{b}}{ }^{\mathrm{b}}$ and ${ }^{\mathrm{c}}$ signifies the level of significance at $1 \%, 5 \%$, and $10 \%$ respectively and LR is log likelihood ratio Source: Author's estimation

LR ratio tests the overall significance of the model. In case of final model (Model 2) the LR ratio is found to be 164.956 and statistically significant at $1 \%$ level of significance. The Model 2 can be directly used to find PDs of firms to assess credit risk.

\section{Model re-estimations}

This section covers re-estimation of Altman, Ohlson and Zmijewski models using estimation sample of 130 Indian firms consisting equal numbers of defaulted and nondefaulted firms. The statistical methodologies are the same used in the original models and discussed in section 2 . The stability of the coefficients of original models is tested by comparing it from re-estimated models. The original and re-estimated coefficients are reported in Table 11. The coefficients of original and re-estimated models are compared to test the stability of coefficients to the time periods and change in the financial conditions. The overall predictive accuracy of model is tested on estimation and holdout sample to test whether change in coefficients (re-estimated) with recent data set improves the predictive accuracy of the model. The newly proposed model is compared with original and re-estimated models. By overall predictive accuracy, ROC, long-range accuracy test and the method to model bankruptcy, it is summarised that the newly proposed model for Indian manufacturing sectors outperforms other competitive models. 


\section{Descriptive statistics}

Tables 8, 9 and 10 reports the descriptive statistics of the variables used in estimation and holdout sample for Altman, Ohlson, and Zmijewski models respectively.

Table 8 shows the profile of variables used in Altman model on estimation and holdout sample. WCTA measures the liquidity of the firm; the mean WCTA for nondistressed group is higher than distressed group in both the sample. RETA measures the earned surplus of the firm. The average RETA for distressed group on both estimation (-0.295) and holdout sample $(-0.843)$ is found to be negative whereas for non-distressed group it is positive on both estimation (0.034) and holdout sample (0.086) respectively.

EBITA measures the true productivity of the firm assets. For defaulted group the mean EBITA is negative for both estimation (-0.100) and holdout (-0.550) and positive for non-defaulted group. BVEBVD is measure of the leverage of the firm. The mean BVEBVD for non-defaulted group for both estimation (0.481) and holdout (3.359) sample is found to be positive for non-defaulted and negative for defaulted groups. SLTA measures the firms' market size. For non-defaulted groups, the size is larger on both estimation (2.013) and holdout (2.522) whereas for defaulted groups its value is smaller on both estimation (0.984) and (1.521) holdout sample respectively.

Table 9 reports the descriptive statistics of the variable used in Ohlson model. SIZE is defined as log of total assets to GNP price-level index. The year 2011-12 is taken 100 as a base value. The mean SIZE for defaulted (0.615) and non-defaulted (0.638) groups is positive and not significantly different on estimation sample. Similarly, mean SIZE for defaulted (-0.587) and non-defaulted (-0.501) is negative and not significantly different from estimation sample. TLTA measures the leverage of firm. For the distressed companies the ratio is higher on both estimation (1.681) and holdout (3.145) sample as compare to non-distressed companies which have lower ratio on both estimation (1.150) and holdout (1.113) sample respectively. The higher ratio for defaulted groups indicates higher leverage.

WCTA is a measure of the current liquidity of the firm. The ratio deteriorates for distressed firms on both estimation (0.215) and holdout (0.634) sample as compare to non-defaulted firms' ratio on estimation (0.553) and holdout sample (1.089) respectively. CLCA is also measure of firm current liquidity. As expected the ratio is higher

Table 8 Descriptive Statistics for Altman Model

\begin{tabular}{lllllll}
\hline Sample & Statistic & WCTA & RETA & EBITA & BVEBVD & SLTA \\
\hline Estimation & & & & & & \\
Distressed $(\mathrm{N}=65)$ & Mean & 0.215 & -0.295 & -0.100 & -0.157 & 0.984 \\
& SD & 0.538 & 0.322 & 0.260 & 0.200 & 1.041 \\
Non-Distressed $(\mathrm{N}=65)$ & Mean & 0.553 & 0.034 & 0.152 & 0.481 & 2.013 \\
& SD & 0.788 & 0.080 & 0.140 & 0.299 & 2.966 \\
Holdout & & & & & & \\
Distressed $(\mathrm{N}=39)$ & Mean & 0.634 & -0.843 & -0.550 & -0.157 & 1.521 \\
& SD & 1.917 & 1.863 & 1.405 & 0.264 & 1.919 \\
Non-Distressed $(\mathrm{N}=39)$ & Mean & 1.089 & 0.086 & 0.214 & 3.359 & 2.522 \\
& SD & 1.406 & 0.136 & 0.230 & 7.173 & 3.111 \\
\hline Source: Author's estimation & & & & & &
\end{tabular}

Source: Author's estimation 
Table 9 Descriptive Statistics for Ohlson Model

\begin{tabular}{lllllllllll}
\hline Sample & Statistic & SIZE & TLTA & WCTA & CLCA & OENEG & NITA & FUTL & INTWO & CHIN \\
\hline Estimation & & & & & & & & & & \\
Distressed $(\mathrm{N}=65)$ & Mean & 0.615 & 1.681 & 0.215 & 0.821 & 0.938 & -0.289 & -0.091 & 0.615 & -0.117 \\
& SD & 1.289 & 0.982 & 0.538 & 0.693 & 0.242 & 0.321 & 0.116 & 0.490 & 0.627 \\
Non-Distressed (N=65) & Mean & 0.638 & 1.150 & 0.553 & 0.560 & 0.338 & 0.044 & 0.129 & 0.077 & 0.057 \\
& SD & 1.121 & 0.873 & 0.788 & 0.427 & 0.477 & 0.094 & 0.371 & 0.269 & 0.503 \\
Holdout & & & & & & & & & & \\
Distressed (N=39) & Mean & -0.587 & 3.145 & 0.634 & 1.116 & 0.949 & -0.843 & -0.153 & 0.590 & -0.236 \\
& SD & 1.219 & 3.282 & 1.917 & 1.197 & 0.223 & 1.863 & 0.209 & 0.498 & 0.682 \\
Non-Distressed (N=39) & Mean & -0.501 & 1.113 & 1.089 & 0.796 & 0.385 & 0.110 & 0.183 & 0.128 & 0.048 \\
& SD & 1.343 & 1.200 & 1.406 & 2.685 & 0.493 & 0.169 & 0.516 & 0.339 & 0.476 \\
\hline
\end{tabular}

Source: Author's estimation

for defaulted firms on both estimation (0.821) and holdout (1.116) sample as compare to non-defaulted firm which have lower ratio on both estimation (0.560) and holdout (0.796) sample respectively. The defaulted firms always expected to have higher ratio because their current liabilities will be always higher than current assets. OENEG is a dummy used for discontinuity correction for TLTA. It takes value 1 if total liabilities exceed total assets, 0 otherwise. NITA is a ratio which measures firms' performance. The ratio deteriorates and found to be negative for bankrupt companies on estimation $(-0.289)$ and holdout $(-0.843)$ sample, whereas it is positive for non-bankrupt firms. FUTL measures the performance of firms'. The result is similar to NITA. The ratio deteriorates and found to be negative for bankrupt companies on estimation (-0.091) and holdout $(-0.153)$ sample where as it is positive for non- bankrupt firms. INTWO is a dummy which takes value 1 , if net income was negative for the last two years, 0 otherwise. CHIN measures the change in the net income of the firm. The CHIN is negative for defaulted groups on both estimation (-0.117) and holdout (-0.236) sample, whereas it is found to be positive for non-defaulted groups on both estimation (0.057) and holdout (0.048) sample respectively.

Table 10 reports descriptive statistics of the variable used in Zmijewski model. NITL in the Table 10 measures return on asset which is measure of firm performance. For

Table 10 Descriptive Statistics for Zmijewski Model

\begin{tabular}{lllll}
\hline Sample & Statistic & NITL & TLTA & CACL \\
\hline Estimation & & & & \\
\multicolumn{1}{c}{ Distressed $(\mathrm{N}=65)$} & Mean & -0.191 & 1.649 & 2.519 \\
& SD & 0.230 & 0.958 & 3.980 \\
Non-Distressed $(\mathrm{N}=65)$ & Mean & 0.360 & 1.131 & 3.496 \\
& SD & 2.586 & 0.861 & 6.428 \\
Holdout & & & & \\
Distressed $(\mathrm{N}=390$ & Mean & -0.192 & 3.054 & 2.603 \\
& SD & 0.602 & 3.173 & 2.925 \\
Non-Distressed $(\mathrm{N}=39)$ & Mean & 0.094 & 1.043 & 4.693 \\
& SD & 0.160 & 1.205 & 6.526 \\
\hline
\end{tabular}


defaulted groups it is negative on both estimation (-0.191) and holdout (-0.192) sample, whereas the ratio is found to be positive for non-bankrupt firm on both estimation (0.360) and holdout (0.094) sample respectively. TLTA is the debt ratio which measures the leverage of the firms. The distressed firms have higher leverage on both estimation (1.649) and holdout sample (3.054) respectively. CACL measures the liquidity of the firms. The non-distressed firm have higher liquidity ratio on both (3.496) and holdout (4.693) sample as compared to distressed groups.

The profile analysis of the samples used in all the three models shows there is significant difference in the mean ratios of the defaulted and non-defaulted groups. The ratios deteriorates for bankrupt groups as compared to non-bankrupt groups.

\section{Results and Discussion}

This section analyzed the findings of the original, re-estimated and newly proposed models on estimation and holdout samples. The stability of their coefficients and their predictive accuracies are also tested. This section also evaluates out of three models which outperforms in the Indian setting.

\section{Unstable coefficients}

Table 11 reports the coefficients of original and re-estimated models. If the models are stable, then their re-estimated coefficient should be also similar. The coefficients of original and re-estimated Altman model are reported in the Table 11.

The result shows there is significant difference in the coefficients of original and reestimated model except RETA. In case of RETA the original (1.4) and re-estimated (1.464) coefficients is found to be very close. For WCTA original coefficient was 1.2, and it ranks third with respect to relative importance of the variable to contribute in the overall index. In the re-estimated model the coefficient (0.076) significantly changes but still its ranks third in term of its relative importance in the overall index. In the original model EBITA, coefficient was 3.3, and it ranks first to contribute in the overall index, whereas re-estimated coefficient $(-.063)$ becomes negative and ranks fifth. In case of BVEBVD, the original coefficient was 0.6 and re-estimated coefficient is 3.474 which is significantly different. For SLTA, the original coefficient was 0.99 and re-estimated coefficient is 0.028 . The * indicates the statistical significance of F-statistic in the difference of mean. For both the Altman original and re-estimated models, the F-statistics is significant, meaning that both the groups defaulted and non-defaulted have significantly different means. The finding suggests the coefficients of Altman (1968) model are not stable, and they are sensitive to time periods.

The results of Ohlson original and re-estimated models are also reported in Table 11. In the original model, all the variables were significant except CLCA, INTWO and constant whereas in the re-estimated model all the variables are significant except SIZE, TLTA, FUTL and INTWO. The coefficients which are significant in both the original and re-estimated models are WCTA, OENEG, NITA, and CHIN. In case of WCTA, the original coefficient was -1.43 and re-estimated coefficient is -5.216 which is significantly different. For OENEG the original coefficient was -1.72 and re-estimated coefficient is 2.836 which is different in value as well as in sign. There is huge difference in the value of NITA coefficient for original $(-2.37)$ and re-estimated $(-29.676)$ model. In 
Table 11 Coefficient Comparison of Different Models

\begin{tabular}{|c|c|c|c|c|c|c|c|}
\hline Statistic & $\begin{array}{l}\text { Altman (1968) } \\
\text { Model }\end{array}$ & $\begin{array}{l}\text { Re-estimated } \\
\text { Model }\end{array}$ & $\begin{array}{l}\text { Ohlson (1980) } \\
\text { Model }\end{array}$ & $\begin{array}{l}\text { Re-estimated } \\
\text { Model }\end{array}$ & $\begin{array}{l}\text { Zmijewski } \\
\text { (1984) Model }\end{array}$ & $\begin{array}{l}\text { Re-estimated } \\
\text { Model }\end{array}$ & $\begin{array}{l}\text { New } \\
\text { Model }\end{array}$ \\
\hline WCTA & $1.2^{\mathrm{a}}$ & $0.076^{\mathrm{a}}$ & $-1.4^{\mathrm{b}}$ & $-5.216^{c}$ & & & \\
\hline RETA & $1.4^{\mathrm{a}}$ & $1.464^{\mathrm{a}}$ & & & & & \\
\hline EBITA & $3.3^{\mathrm{a}}$ & $-0.63^{a}$ & & & & & \\
\hline BVEBVD & $0.6^{\mathrm{a}}$ & $3.474^{\mathrm{a}}$ & & & & & $-13.86^{\mathrm{a}}$ \\
\hline SLTA & 0.99 & $0.028^{\mathrm{a}}$ & & & & & $-1.113^{c}$ \\
\hline SIZE & & & $-0.4^{\mathrm{a}}$ & 0.079 & & & \\
\hline TLTA & & & $6.03^{\mathrm{a}}$ & 1.623 & $5.7^{\mathrm{a}}$ & $0.586^{\mathrm{a}}$ & \\
\hline CLCA & & & $0.1^{\mathrm{b}}$ & $-2.973^{b}$ & & & \\
\hline OENEG & & & $-2.4^{\mathrm{a}}$ & $2.836^{\mathrm{b}}$ & & & \\
\hline NITA & & & $-1.8^{\mathrm{b}}$ & $-29.676^{a}$ & & & $-18.76^{b}$ \\
\hline FUTL & & & $0.3^{\mathrm{a}}$ & -2.559 & & & \\
\hline INTWO & & & -1.7 & 0.337 & & & \\
\hline $\mathrm{CHIN}$ & & & $-0.5^{\mathrm{a}}$ & $1.73^{\mathrm{c}}$ & & & \\
\hline NITL & & & & & $-4.5^{\mathrm{a}}$ & $-13.797^{a}$ & $-34.354^{b}$ \\
\hline CACL & & & & & $0.004^{b}$ & 0.01 & \\
\hline Constant & & -0.425 & -1.3 & $-2.454^{c}$ & $-4.3^{\mathrm{a}}$ & $-1.522^{\mathrm{a}}$ & -0.604 \\
\hline$L R$ & & & $0.839^{d}$ & -15.952 & 203.78 & -33.296 & 164.956 \\
\hline$P$-value & & & 0.000 & 0.000 & 0.000 & 0.000 & 0.000 \\
\hline
\end{tabular}

Note: ${ }^{a}{ }^{b}$ and ${ }^{c}$ represents the level of significance at 1 per cent, 5 per cent and 10 per cent respectively. $d$ is the Likelihood Ratio Index and LR is the Log Likelihood Ratio

Source: Author's estimation

case of CHIN, the original (-0.5) and re-estimated (1.73) coefficient are not only different in value but also in sign. The result shows the coefficients of Ohlson (1980) model is sensitive to time period and not stable.

Finally, the result of Zmijewski model is again reported in Table 11. In the original model, all the coefficients are significant whereas in the re-estimated model all the variables are significant except CACL (Current assets to current liabilities). Rest other coefficients preserve similar sign but different in the magnitude. In case of TLTA, the original coefficients were 5.7 and re-estimated is 0.586 which is significantly different in magnitude. For NITL the original coefficients was -4.5 and re-estimated co-efficient is -13.797 . The constant term in both the original $(-4.3)$ and re-estimated (-1.222) is different in values. The result shows the coefficients of Zmijewski (1984) model is sensitive to time period and not stable. The results of newly proposed model are reported in the last column of Table 11. All the variables are significant except intercept.

The results reported in Table 11 shows coefficient of all the three accounting based models are not similar. They are unstable and sensitive to time period. The findings are in line with the studies of Grice and Ingram (2001), Grice and Dugan (2001), Timmermans (2014) and Avenhuis (2013). Empirically it is found in the context of Indian manufacturing sector the coefficients are unstable and sensitive to time periods.

\section{Predictive accuracy}

Predictive accuracy of all the original, re-estimated and newly proposed models on estimation and holdout sample is reported in Table 12. In the earlier section, we have 
mentioned based upon total error minimization principle, cut-off value is taken for all the three models. The cut-off value for original Altman (1968), Ohlson (1980) and Zmijewski (1984) models were 2.675, 0.5 and 0.5 respectively (Ohlson 1980 page 120; Zmijewski 1984 page 72). In the re-estimated model based upon the same principle the cut-off value for Altman, Ohlson and Zmijewski model is taken 0, 0.4 and 0.5 respectively. For the newly proposed model same principle of total error minimization criterion is followed and 0.6 is taken cut-off value for the model (Appendix 1, Table 14).

Panel-A of the Table 12 reports the predictive accuracy of original, re-estimated and newly proposed models on estimation sample. The predictive accuracy of original Altman model on estimation sample is $67.692 \%$ which correctly classify $92.308 \%$ of distressed and $43.077 \%$ of non-distressed firm. The Type II error is very high in case of Altman original model on estimation sample. The overall accuracy of Altman reestimated model on estimation sample is 96.923 which correctly classify $98.462 \%$ of distressed and $95.385 \%$ of non-distressed firms. For Ohlson original model the overall predictive accuracy is $48.462 \%$ on estimation sample which correctly classifies $95.385 \%$ of distressed firms and $1.538 \%$ of non-distressed firms. The Type II error in the case of Ohlson original model on estimation sample is close to $100 \%$. On the other hand, overall predictive accuracy of re-estimated Ohlson model is 95.385 which correctly classifies $96.923 \%$ of defaulted and $93.846 \%$ of non-defaulted firms. In case of Zmijewski original model, the overall predictive accuracy is $71.538 \%$. The model correctly classify $98.462 \%$ of distressed and $44.615 \%$ of non-distressed firms. The overall predictive accuracy of re-estimated Zmijewski model on estimation sample is found to be 89.231 which correctly classify $87.692 \%$ of defaulted and $90.769 \%$ of non-defaulted firms. In case of newly proposed model, the predictive accuracy on estimation sample is found to be 98.46 which correctly classify $98.46 \%$ of distressed and $98.46 \%$ of nondistressed firm. The Type I and Type II error in case of new model is found to be equal. Panel-A of Table 12 shows predictive accuracy of re-estimated models is higher than original model on estimation sample. The newly proposed model have highest (98.46) predictive accuracy with minimum and equal Type I and Type II errors. Type II error

Table 12 Comparison of Predictive Accuracy of the Models

\begin{tabular}{|c|c|c|c|c|c|c|}
\hline \multirow[b]{3}{*}{ Model } & \multicolumn{6}{|c|}{ Panel-A (Estimation Sample) } \\
\hline & \multicolumn{3}{|c|}{ Original model Accuracy } & \multicolumn{3}{|c|}{ Re-estimated model Accuracy } \\
\hline & Overall & Distressed & Non-Distressed & Overall & Distressed & Non-Distressed \\
\hline Altman & 67.692 & 92.308 & 43.077 & 96.923 & 98.462 & 95.385 \\
\hline Ohlson & 48.462 & 95.385 & 1.538 & 95.385 & 96.923 & 93.846 \\
\hline Zmijewski & 71.538 & 98.462 & 44.615 & 89.231 & 87.692 & 90.769 \\
\hline \multirow[t]{4}{*}{ New Model } & 98.460 & 98.460 & 98.460 & NA & NA & NA \\
\hline & \multicolumn{6}{|c|}{ Panel-B (Holdout Sample) } \\
\hline & \multicolumn{3}{|c|}{ Original model Accuracy } & \multicolumn{3}{|c|}{ Re-estimated model Accuracy } \\
\hline & Overall & Distressed & Non-Distressed & Overall & Distressed & Non-Distressed \\
\hline Altman & 61.538 & 25.641 & 97.436 & 88.462 & 87.179 & 89.744 \\
\hline Ohlson & 64.103 & 97.436 & 30.769 & 89.744 & 87.179 & 92.308 \\
\hline Zmijewski & 79.487 & 97.436 & 61.538 & 76.923 & 61.538 & 92.308 \\
\hline New Model & 87.179 & 82.051 & 92.308 & NA & NA & NA \\
\hline
\end{tabular}

Source: Author's estimation 
is found to be more than $50 \%$ in all the three original models. In case of original Ohlson model, the Type II error is close to $100 \%$. All the three re-estimated models have higher predictive accuracy and low Type I and Type II errors compared to original models.

Panel-B of Table 12 reports the predictive accuracy of original, re-estimated and newly proposed models on holdout sample. The overall accuracy on holdout sample also constitutes diagnostic test for the estimated models. The overall accuracy of Altman original model on holdout sample is 61.538 \% which correctly classifies $25.641 \%$ of defaulted and $97.436 \%$ of non-defaulted firms. The Type I error in case of Altman original model on holdout sample is very high and close to $75 \%$. On the other hand, overall predictive accuracy of Altman re-estimated model is $88.462 \%$ which correctly classifies $87.179 \%$ of defaulted and $89.744 \%$ of non-defaulted firms. In case of Ohlson original model, the overall predictive accuracy is found to be $64.103 \%$ which correctly classify $97.436 \%$ of distressed and $30.769 \%$ of non-distressed firms. The Type II error in the case of Ohlson original model on holdout sample is close to $70 \%$. On reestimated Ohlson model, the overall predictive accuracy is $89.744 \%$ which correctly classifies $87.179 \%$ of defaulted and 92.308 non-defaulted firms. The predictive accuracy of Zmijewski original model on holdout sample is $79.487 \%$ which correctly classifies $97.436 \%$ of distressed and $61.538 \%$ of non-distressed firms. The Type II error in case of original Zmijewski model on holdout sample is close to $40 \%$. The overall predictive accuracy of re-estimated Zmijewski model on holdout sample is 79.487 \% which correctly classifies $97.436 \%$ of distressed and $61.538 \%$ of non-distressed firms. On holdout sample, the Type II error is again high for original models except Altman model. The Type II error in case of both Ohlson and Zmijewski original model is more than $50 \%$. In case of all the re-estimated models both the Type I and Type II errors are minimum except Zmijewski model. In case of new model the overall predictive accuracy on holdout sample is found to be 87.179 \% which correctly classifies $82.051 \%$ of defaulted and $92.307 \%$ of non-defaulted firms. The Type I error in case of new model is found to be $18 \%$ and Type II error close to $8 \%$.

From the results reported in Panel-A and B of Table 12 on estimation and holdout sample, it can be summarized that the predictive accuracy of re-estimated models are significantly higher than original models on both estimation and holdout sample. Except Altman model the Type II error is very high for all the original models on both estimation and holdout sample. The result shows the model applied on the recent data set gives higher predictive accuracy on both estimation and holdout sample. Out of contesting accounting based models, the new model outperforms regarding its predictive accuracy on estimation sample and fairly good accuracy on holdout sample for Indian manufacturing firms. The overall predictive accuracy of re-estimated Ohlson model is 95.385 and 89.385 on estimation and holdout sample respectively. The overall predictive accuracy of Altman re-estimated model is also close to new model, but new model is better than Altman model because it gives direct probability estimates and model bankruptcy in a non-linear fashion which is in line with local and global regulatory framework. In the next section, we will apply other diagnostic check to check the stability of Ohlson re-estimated model. The results are in line with the studies of Grice and Ingram (2001), Grice and Dugan (2001), Timmermans (2014) and Avenhuis (2013). Empirically it is found in the context of Indian manufacturing sector that the coefficients are unstable and sensitive to time periods. 


\section{Diagnostics check for the New Model}

This section deals with two diagnostics tests for newly proposed model, ROC and longrange accuracy test.

The ROC (Hanley and McNeil, 1982) is one of the important and widely used test to assess the performance of a binary classifier. The Area Under the Curve (AUC) summarizes the performance of a model in a single number. The accuracy of the test depends upon how well it classifies between the groups. In the present context, it is between bankrupt and non-bankrupt. The model ROC with AUC 1 shows the perfect test whereas the model with AUC 0.5 shows worthless test. As compare to a simple metric of misclassification rate, ROC visualizes all possible classification thresholds.

In the ROC test the sensitivity or positive predictive value (PPV) is defined as the proportion of firms for whom the outcome is positive that are correctly identified. Similarly, the specificity or negative predictive value (NPV) is the probability that a firm has a negative outcome given that they have a negative test result.

The ROC is the graph of specificity against 1-senstivity by which the impact of choice is understood. A fairly excellent test have good balance between sensitivity and specificity. The decision to set the classification threshold to predict out-of-sample data depends upon the business decision.

Figure 1 shows the AUROC for re-estimated and new proposed model for bankruptcy prediction. From the results, it is clear that new model shows the best results as compare to other contesting models in application to the control. The AUROC for new model is .985 which is higher than other contesting models. Hence, we can say this model is the most appropriate model among contesting models for prediction of the corporate failure for Indian manufacturing firms.

Table 13 reports the long-range accuracy results of new model on estimation and hold-out sample. The long range accuracy of new model on estimation sample are 98.46 and $86.92 \%$ for one year before bankruptcy and two years before bankruptcy respectively. On the holdout sample, it is 89.74 and $70.51 \%$ for one year and two years before default respectively.

The long range accuracy results are fairly good and satisfactory. The result shows the predictive accuracy of new model decreases as we go more backward from the year of distress. Hence, the most recent information is helpful in predicting default with higher accuracy.

\section{Conclusion}

The paper proposed a new model to predict the bankruptcy of Indian manufacturing sector and also examines the sensitivity of Altman's (1968), Ohlson's (1980) and Zmijewski's (1984) models to the sample of 208 equal numbers of defaulted and non-defaulted firms for the period 2006 to 2014 in the Indian context. The result shows the overall accuracy of the model improves when the coefficients are reestimated. The overall accuracy of Altman (1968), Ohlson (1980) and Zmijewski (1984) original models in the estimation sample are 67.692, 48.462 and $71.538 \%$ respectively. When all the models are re-estimated the accuracy improves to 96.923 , 95.385 and $89.231 \%$ respectively. On holdout sample, the overall accuracy of Altman's (1968), Ohlson's (1980) and Zmijewski's (1984) original models are 61.538, 64.103 and $79.487 \%$ respectively. The accuracy improves to $88.462,89.744$ and 


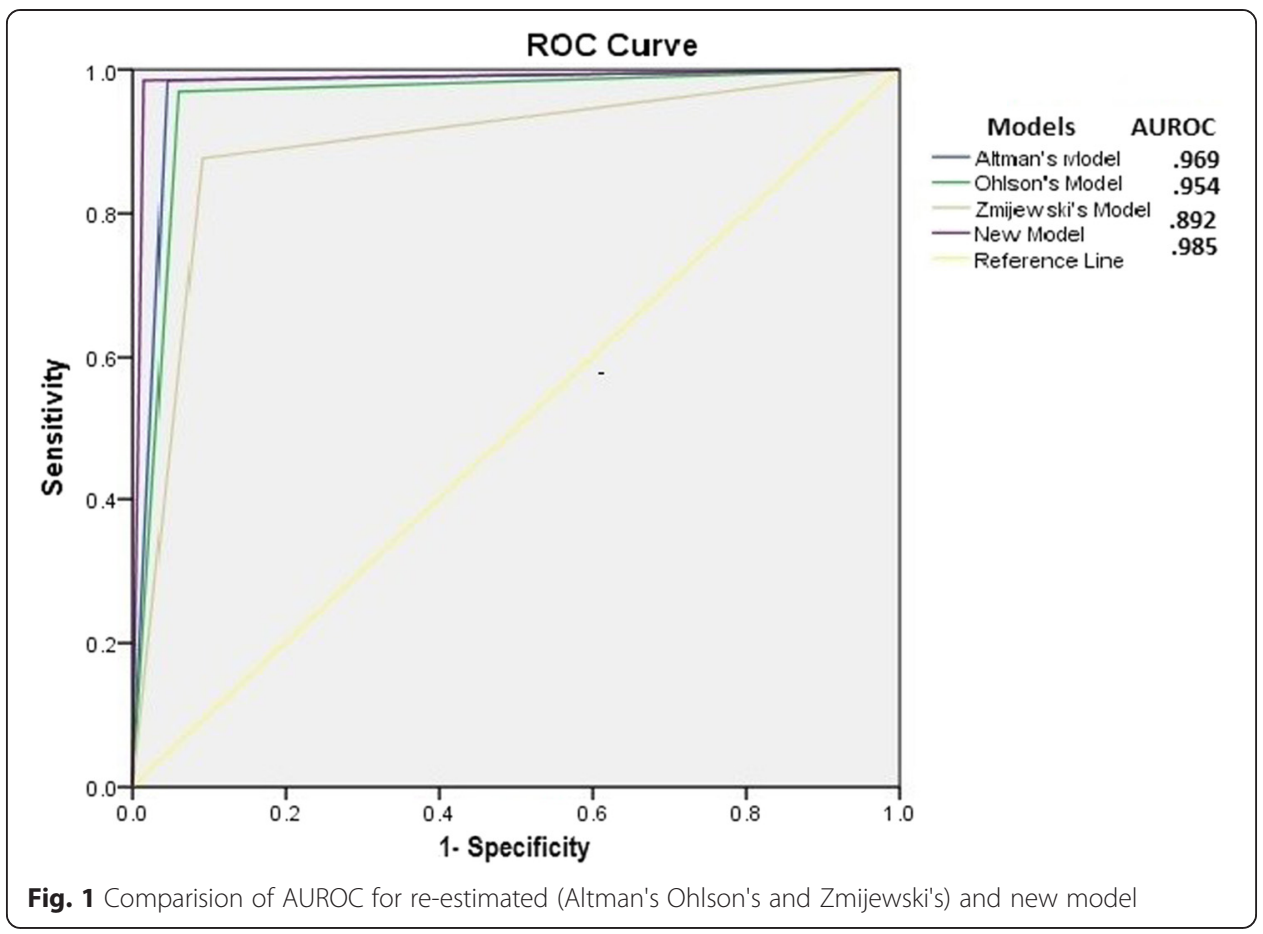

76.923 when the models are re-estimated. The predictive accuracy of new model on estimation and holdout sample is found to be 98.46 and 87.179 respectively. Therefore, the new model is found to be a more robust model in comparison to Altman's, Ohlson's and Zmijewski's models. The major finding of the study suggests the coefficients of the Altman's (1968), Ohlson's (1980) and Zmijewski's (1984) models are sensitive to time periods and financial condition. The predictive accuracy of the models increases when more recent data are used in the estimation samples. The change in the financial environment leads to change in the relation between financial distress and financial ratios. This also alters the comparative importance of the ratios to predict default. Hence, researchers should re-estimate the original models to get higher predictive accuracy. In case of Indian manufacturing companies, out of all competitive accounting based models, the new model outperforms regarding predictive accuracy, $\mathrm{ROC}$, and long-range accuracy test.

The major limitation of the study is that it can be applied to only manufacturing firms and excludes financial firms. The study can also use larger data set applying various other parametric and non-parametric models to check validity of the model, robustness and stability of the parameters. Though, the results of Black-Scholes-Merton (BSM) model can't be directly compared with the proposed model but using Indian manufacturing data the same approach can be applied to develop model for Indian manufacturing companies.

Table 13 Long-range Accuracy of Newly Proposed Model

\begin{tabular}{lll}
\hline Years before distress & Estimation sample & Holdout Sample \\
\hline 1 & 98.460 & 89.743 \\
2 & 86.923 & 70.513 \\
\hline
\end{tabular}




\section{Endnotes}

${ }^{1}$ The total error minimization principle is applied to obtain cutoff value. Various cutoff values are tested and the final cutoff value is decided where the sum of Type I and Type II errors are minimized. Type I errors occur when a model incorrectly classifies a distressed company as non-distressed, while Type II errors occur when a model incorrectly classifies a non-distressed company as distressed.

\section{Appendix 1}

Table 14 Identification of Cutt-off Value for Re-estimated and Newly Proposed Model

\begin{tabular}{lccc}
\hline Cut-off & Overall Correct Prediction & Type I Error & Type II Error \\
\hline Altman's re-estimated Model & & & \\
0 & 96.923 & 1.538 & 4.615 \\
0.2 & 92.308 & 1.538 & 13.846 \\
0.3 & 91.538 & 1.538 & 15.385 \\
0.4 & 90.000 & 1.538 & 18.462 \\
Ohlson's re-estimated Model & & & \\
0.7 & 93.850 & 3.080 & 9.230 \\
0.6 & 94.620 & 4.620 & 6.150 \\
0.5 & 94.620 & 6.150 & 4.620 \\
0.4 & 95.380 & 6.150 & 3.080 \\
Zmijewski's re-estimated Model & & & 24.620 \\
0.7 & 86.150 & 3.080 & 24.620 \\
0.6 & 85.380 & 4.620 & 12.310 \\
0.5 & 89.230 & 9.230 & 9.230 \\
0.4 & 88.460 & 13.850 & \\
Newly proposed Model & & & 0.000 \\
0.7 & 98.460 & 3.080 & 1.540 \\
0.6 & 98.460 & 1.540 & 3.080 \\
0.5 & 97.690 & 1.540 & 1.540 \\
0.4 & 97.690 & & \\
\hline
\end{tabular}

Source: Author's estimation

Competing interests

The authors declare that they have no competing interests.

Authors' contributions

BPS collected the study material, design the concept, collected data, interpreted the results and drafted the manuscript. AKM participated in the study design, statistical analysis and interpretation of results and helped to draft the manuscript. Both authors read and approved the final manuscript.

Authors' information

Bhanu Pratap Singh is a Doctoral Fellow and Alok Kumar Mishra is an Assistant Professor.

Received: 9 January 2016 Accepted: 27 May 2016

Published online: 09 June 2016

References

Abdullah NA, Halim A, Ahmad H, Russ RM (2008) Predicting corporate failure of Malaysia's listed companies: comparing multiple Discriminant analysis, logistic regression and hazard model. Int Res J Financ Econ 15:201-217 Adnan M, Dar AH (2006) Predicting corporate bankruptcy: where we stand? Corp Gov 6(1):18-33 Agarwal V, Taffler RJ (2008) Comparing the performance of market-based and accounting based bankruptcy prediction models. J Bank Financ 32:1541-1551 
Altman El (1968) Financial ratios, discriminant analysis and the prediction of corporate bankruptcy. J Financ 23(4):189-209 Altman El (1993) Corporate Financial Distress and Bankruptcy. John Wiley and Sons, Inc., New York

Altman El, Levallee MY (1980) Business Failure Classification in Canada. J Bus Adm 12(1):147-164

Altman El, Haldeman R, Narayanan P (1977) ZETA analysis, a new model for bankruptcy classification. J Bank Financ 1(1):29-54

Altman El, Marco G, Varetto F (1994) Corporate distress diagnosis: Comparisons using linear discriminant analysis and neural networks (the Italian experience). J Bank Financ 18(3):505-529

Argenti I (1976) Corporate Collapse: The Causes and Symptoms. McGraw-Hill, London

Avenhuis JO (2013) Testing the generalizability of the bankruptcy prediction models of Altman,Ohlson and Zmijewski for Dutch listed and large non-listed firms. Thesis submitted to School of Management and Governance. University of Twente, Netherlands

Balcaen S, Ooghe H (2004) 35 years of studies on business failure: an overview of the classical statistical methodologies and their related problems. Working paper. Ghent University, June, 248: 1-62

Bandyopadhya A (2006) Predicting probability of default of Indian corporate bonds: logistic and Z-score model approaches. J Risk Financ 7(3):255-272

Beaver WH (1966) Financial ratios as predictors of failures. Journal of Accounting Research, Empirical Research in Accounting: Selected Studies 4:71-111

Begley J, Ming J, Watts S (1996) Bankruptcy classification errors in the 1980s: An empirical analysis of Altman's and Ohlson's models. Rev Acc Stud 1:267-284

Bellovary J, Giacomino D, Akers M (2007) A review of bankruptcy prediction studies: 1930-present. J Financ Educ 33:1-42

Bharath ST, Shumway T (2008) Forecasting default with the Merton distance to default model. Rev Financ Stud 21:1339-1369

Bhunia A, Sarkar R (2011) A study of financial distress based on MDA. J Manag Res 3(2):1-11

Black F, Cox J (1976) Valuing corporate securities: Some effects of bond indenture provisions. J Financ 31:352-367

Black F, Scholes M (1973) The pricing of options and corporate liabilities. J Polit Econ 81(3):637-654

Blum M (1974) Failing company discriminant analysis. J Account Res 12(1):1-25

Boritz JE, Kennedy DB, Sun JY (2007) Predicting Business Failures in Canada. Account Perspect 6:141-165

Charalambous C, Charitou A, Kaourou F (2000) Comparative analysis of artificial neural network models: Application in bankruptcy prediction. Ann Oper Res 99:403-425

Chudson W (1945) The Pattern of Corporate Financial Structure. National Bureau of Economic Research, New York

Coats PK, Fant LF (1993) Recognizing financial distress patterns using a neural network tool. Financ Manag 22:142-155

Deakin E (1972) A discriminant analysis of predictors of business failure. J Account Res 10(1):167-179

Dimitras Al, Slowinski RS, Zoupounidis C (1999) Business failure prediction using rough sets. Eur J Oper Res 114(2):263-280

Duffie D, Singleton K (1999) Modeling term structures of defaultable bonds. Rev Financ Stud 12:197-226

Eljelly A, Mansour I (2001) Predicting private companies failure in the Sudan. J Afr Bus 2(2):23-43

Etemadi H, Rostamy AAA, Dehkordi HF (2009) A genetic programming model for bankruptcy prediction: Empirical evidence from Iran. Expert Syst Appl 36(2):3199-3207

Fejér-Király G (2015) Bankruptcy Prediction: A Survey on Evolution, Critiques, and Solutions. Acta Universitatis Sapientiae, Economics and Business 3(1):93-108

FitzPatrick P (1932) A comparison of ratios of successful industrial enterprises with those of failed companies. The Certified Public Accountant (October, November, December): 598-605, 656-662, and 727-731, respectively

Fulmer J, Moon J, Gavin T, Erwin M (1984) A bankruptcy classification model for small firms. Journal of Commercial Bank Lending 66:25-37

Georgeta V, Georgia TM (2012) Bankruptcy Prediction Model for Listed Companies in Romania. Journal of Eastern Europe Research in Business \& Economics Article ID 381337, DOI: 10.5171/2012.381337

Grice JS, Dugan M (2001) The limitations of bankruptcy prediction models: Some cautions for the researcher. Rev Quant Finan Acc 17:151-165

Grice JS, Ingram RW (2001) Tests of the Generalizability of Altman's Bankruptcy Prediction Model. J Bus Res 54(1):53-61

Gu Z (2002) Analyzing bankruptcy in the restaurant industry: a multiple discriminant model. Int J Hosp Manag 21(1):25-42

Guan Q (1993) Development of optimal network structures for back-propagationtrained neural networks. Ph.D. dissertation. University of Nebraska, Nebraska

Gupta J, Gregoriou A, Healy J (2014) Forecasting bankruptcy for SMEs using hazard function: To what extent does size matter? Rev Quant Finan Acc 2:1-25

Hanley JA, McNeil BJ (1982) The meaning and use of the area under a Receiver Operating Characteristics curve. Radiology 143:29-36

Hillegeist S, Keating E, Cram D, Lundstedt K (2004) Assessing the probability of bankruptcy. Rev Acc Stud 9:5-34

Izan H (1984) Corporate distress in Australia. J Bank Financ 8(2):303-320

Jackendoff N (1962) A Study of Published Industry Financial and Operating Ratios. Temple University, Bureau of Economic and Business Research, Philadelphia

Jarrow R, Turnbull S (1995) Pricing derivatives on financial securities subject to credit risk. J Financ 50:53-85

Jensen MC (1989) Active Investors, LBOs and the Privatization of Bankruptcy. Journal of Applied Corporate Finance 2(1): 35-44.

Kirkos E (2015) Assessing methodologies for intelligent bankruptcy prediction. Artif Intell Rev 43:83-123

Koro T, Korodi A (2011) An evaluation of effectiveness of Fuzzy logic model in predicting the business bankruptcy. Romanian Journal of Economic Forecasting 3:92-107

Kulkarni A, Mishra AK, Thakker J (2005) How Good is Merton Model at Assessing Credit Risk? Evidence from India. National Institute of Bank Management

Kumar MN, Rao VSH (2015) A New Methodology for Estimating Internal Credit Risk and Bankruptcy Prediction under Basel II Regime. Comput Econ 46(1):83-102

Laitinen EK (1992) Prediction of failure of a newly founded firm. J Bus Ventur 7(4):323-340

Lando D (1994) Three essays on contingent claims pricing. Ph.D. dissertation. Cornell University

Lee S, Choi WS (2013) A multi-industry bankruptcy prediction model using back-propagation neural network and multivariate discriminant analysis. Expert System with Applications 40:2941-2946 
Lee KC, Han I, Kwon Y (1996) Hybrid neural network models for bankruptcy predictions. Decis Support Syst 18(1):63-72 Legault J, Veronneau P (1986) CA-Score, Un Modele De Prevision De Faillite. ResearchReport

Leland H, Toft K (1996) Optimal capital structure, endogenous bankruptcy, and the term structure of credit spread. J Financ 51:987-1019

Lonfstaff F, Schwartz E (1995) A simple approach to valuing risky fixed and floating rate debt. J Financ 50:789-819 Merton R (1974) On the pricing of corporate debt: The risk structure of interest rates. J Financ 29:449-470

Merwin C (1942) Financing small corporations in five manufacturing industries, 19261936. National Bureau of Economic Research, New York

Messier W Jr, Hansen J (1988) Inducing rules for expert system development: an example using default and bankruptcy data. Manag Science 34(12):1403-1415

Molinero M, Ezzamel M (1991) Multidimensional Scaling Applied to Corporate Failure. Omega Int J Manag Sci 19(4):259-274

Neophytou E, Charitou A, Charalambous C (2001) Predicting corporate failure: Empirical evidence for the UK. Discussion Paper No. 01-173, March, School of Management. University of Southampton, Southampton

Ohlson JA (1980) Financial ratios and the probabilistic prediction of bankruptcy. J Account Res 18(1):109-131

Platt DH, Platt MB (1990) Development of a class of stable predictive variables: The case of bankruptcy prediction. J Bus Financ Account 17:31-5

Platt HD, Platt MB (2002) Predicting corporate financial distress: reflections on choice-based sample bias. J Econ Financ 26(2):184-199

Pongsatat S, Ramage J, Lawrence H (2004) Bankruptcy prediction for large and small firms in Asia: a comparison of Ohlson and Altman. J Account Croporate Governance 1(2):1-13

Premachandra IM, Bhbra GS, Sueyoshi T (2009) DEA as a tool for bankruptcy assessment: A comparative study with logistic regression technique. Eur J Oper Res 193:412-424

Raghupathi W, Schkade LL, Raju BS (1991) A neural network application for bankruptcy prediction. In System Sciences, 1991. Proceedings of the Twenty-Fourth Annual Hawaii International Conference IEEE 4:147-155

Ramakrishnan PR (2005) Financial Distress Prediction Models: A Case of Potential Sick Companies in India. The ICFAI Journal of applied Finance 68-77. http://www.iupindia.in/1005/JAF_Financial_Distress_68.html

Shetty U, Pakkala TPM, Mallikarjunappa T (2012) A modified directional distance formulation of DEA to assess bankruptcy: An application to IT/ITES companies in India. Expert Systems with Applications 39(2):1988-1997

Smith R, Winakor A (1935) Changes in Financial Structure of Unsuccessful Industrial Corporations. Bureau of Business Research, Bulletin No. 51. University of Illinois Press, Urbana

Springate GLV (1978) Predicting the Possibility of Failure in a Canadian Firm. Unpublished M.B.A. Research Project, Simon Fraser University

Timmermans M (2014) US Corporate Bankruptcy Prediction Models: How accurate are the bankruptcy predicting models of Altman (1968), Ohlson (1980) and Zmijewski (1984) after recalibration, when they are applied to U.S. listed firms in the period after the BACPA change in bankruptcy law? Thesis submitted to Tilburg University School of Economics and Management. ANR: 876937

Tsukuda J, Baba SI (1994) Predicting Japanese corporate bankruptcy in terms of financial data using neural network. Comput Ind Eng 27(1):445-448

Ugurlu M, Aksoy H (2006) Prediction of corporate financial distress in an emerging market: the case of Turkey: Cross Cultural Management. Int J 13(4):277-295

Vareto F (1998) Genetic algorithms applications in the analysis of insolvency risk. J Bank Financ 22:1421-1439

Varma JR, Raghunathan V (2000) Modeling credit risk in Indian bond markets. ICFAl Journal of Applied Finance 6(3):53-67

Verikas A, Kalsyte Z, Bacauskiene M, Gelzinis A (2010) Hybrid and ensemble-based soft computing techniques in bankruptcy prediction: a survey. Soft Comput 14:995-1010

Wu Y, Gaunt C, Gray S (2010) A comparison of alternative bankruptcy prediction models. J Contemp Account Econ 6:35-45

Zmijewski ME (1984) Methodological issues related to the estimation of financial distress prediction models. J Account Res 22:59-82

\section{Submit your manuscript to a SpringerOpen ${ }^{\circ}$ journal and benefit from:}

- Convenient online submission

- Rigorous peer review

- Immediate publication on acceptance

- Open access: articles freely available online

- High visibility within the field

- Retaining the copyright to your article 